\title{
The simple living of Leo Tolstoy and the slippery slope of consumerism in a context of poverty: A pastoral guide
}

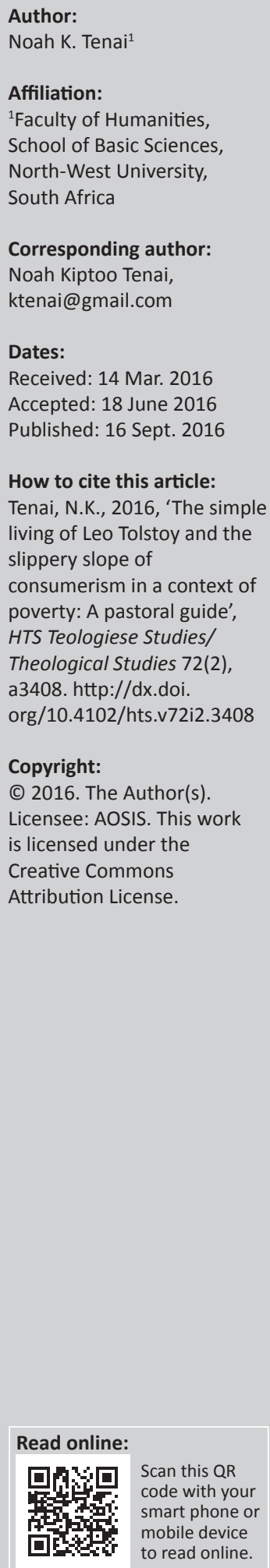

\begin{abstract}
The nature of consumerism, which manifests in the belief that excessive accumulation of material goods represents a fuller and more meaningful life, is a growing global phenomenon, and has an effect on both the 'haves' and the 'have-nots'. In addition, poverty levels globally and in Kenya in particular, remain unacceptably high. The situation of poverty in Kenya is partly worsened by the trapping effects of consumerism. The life of a wealthy and prosperous writer, Leo Tolstoy, who succumbed to depression in spite of his fame and material wealth, is examined with a view to establish how he overcame his depression and found meaning in life. The lessons he learnt from turning to a study of the peasantry are extrapolated and proposed for the churches' response to the challenge of consumerism in contexts of poverty.
\end{abstract}

\section{Introduction}

Within a global context of rising and escalating consumerism, combined with a local challenge of unending and ever dehumanising poverty, the question that guides this article is: What is the meaning and significance of the life and values of Leo Tolstoy and how can the notion of 'simple living' be appropriated by churches to respond responsibly and adequately to the challenge of consumerism within a context of poverty?

It is a difficult task to describe what consumerism is. The meaning(s) of the term is a subject of different opinions and interpretations. There are various shades and emphases placed on the term. However, a clearly delineated understanding of how this term is used in this article is important, particularly in order to demonstrate the challenge(s) that consumerism poses to those living in poverty. Establishing a working definition for consumerism is a daunting but not a hopeless task, as the variations in the use of the term in various literatures cannot be ignored. It is important that anyone using the term makes the meaning clear.

To demonstrate this point, three uses of the term are provided. The first use of the term refers to the consumer movement and its efforts to protect the consumer's interests (Swagler 1994:348-351; German 1991:29; Greer 1944:274; Swagler 1994:351-352; Aaker \& Day 1971:xvii; Cohen 1967:4; Nader 1968:26). Although the origins of consumerism are hard to establish, by the 1960s reference was made to the consumer movements. The term was coined during the earlier years of the consumer movement and became an epithet used to supress the movement's emergence. The term may have first been used in the 1940s to suggest elimination of waste and needless tolls in the retail and wholesale distribution. As such, the term reflected the important role of cooperatives in the consumer movement through the 1930s. In this sense, the term is appropriated to describe the various reforms associated with the consumer movement.

The second use of the term represents consumer sovereignty and power (Brobeck 1990:xvi; German 1991:26; Swagler 1994:352-354; Swagler 1979:164). It is about efforts by consumers to attain a marketing system, which makes the consumer sovereign, with a secure and a just economic system. Consumer protection laws, availability of products and price information are envisaged. Consumers call for a balance, including government's intervention on their behalf in the market place. It is about a just economic environment and the protection of consumer's interests.

The third use of the term represents excessive materialism (Swagler 1994:354-356; Coontz 1992:169, 179; Lawlor 1988:9). It is about crass materialism. It is a preoccupation with material things and a frivolous accumulation of goods for their own sake. The usage of the term in this sense is derogatory,

Note: This article is published in the section Practical Theology of the Society for Practical Theology of South Africa. 
as it goes against self-restraint. In recent years, the term has become more common as a highly destructive force.

For the purposes of this article, consumerism shall represent sentiments discussed in the third use of the term above. Stated differently, consumerism shall be understood as an unrestrained, rampant and self-indulgent excessive materialism that manifests in the frivolous accumulation of material goods. It is a belief that one's well-being and completeness depends to a very large extent on material consumption.

Similar to the forgone arduous venture to describe consumerism is any effort to give a definition to poverty. It is an onerous attempt, because of poverty's multifacetedness. Poverty has economic, social and political features, which manifest as insufficiency, inadequacy, inability, lack and deprivation. Various sources (Goulden \& D'Arcy 2014:3-8; Korayem \& Mashhour 2014:2-7; Townsend 2013:4-25, 27-39, 79-95; Hagenaars 1986:1-15, 44-54) demonstrate this multifacetedness. As such poverty is identified in terms of low income, inability to access credit, inability to get a job to earn a living and the general insufficient capacity to better one's life due to an inability to acquire basic goods and services necessary for survival with dignity, such as land, education, health, food, water, clothing and sanitation. Poverty means living in marginality and in fragile environments. It is susceptibility to violence, lack of adequate security and lack of a voice. It is exclusion, powerlessness and the general lack of capacity to participate effectively in society. Poverty is the deprivation of well-being; it is the inability to access choices and opportunities. It is a violation of human dignity.

Stated differently, poverty is a dehumanising factor. It is everything that takes away the very humanity of human beings. Poverty is what stands in the way of humanity's very humanity. It is a deprivation of human qualities requisite to living life in all its fullness.

The article investigates the impact of consumerism in Kenya, particularly among those who live in poverty. The article interrogates the significance of 'simple living', through and from the perspective of the life of Leo Tolstoy and how it can be appropriated by the churches of the Africa Inland - Kenya, to respond soundly to the challenge of consumerism within contexts of poverty.

\section{A rising and escalating consumerism}

High levels of consumerism globally are clearly documented. Available figures paint a picture of global excessive and unnecessary consumption and accumulation (De Graaf 2014:28-33; WorldWatch 2013:1 of 1; The Telegraph 2010: 1 of 1; Dwyer 2007:23-25). The data shows that by virtually any measure, household expenditure and consumption of goods has risen steadily in industrialised nations and is growing rapidly in developing countries. By 2013, there were more than 1.7 billion 'consumer class', nearly a half of them were from the developing world. It is argued that a lifestyle and culture that became common in Europe, North America and other parts of the so-called developed world in the 20th century is going global in the 21st century. The global amount spent on the purchase of goods at household level topped \$20 trillion (United States dollars) in the year 2000. Consumerism is manifesting contemporarily in terms of the rapid growth in the average size of housing and the ever increasing amount of living space per person. Large new houses need to be filled with 'stuff', such as bigger televisions and 'home theatres', exercise equipment, spacious designer kitchens and several car garages. The data shows the ever increasing consumption of electronic gadgets, such as new smart phones. The clothing industry is never left behind, as fashion shops that sell particular fashion labels mushroom at every corner in cities. In some countries, shopping malls are beginning to outnumber high schools and expenditure in shoes, jewellery and watches is bigger than that spent on high school education. A British research (The Telegraph 2010:1 of 1) found that the average 10-year-old owns 238 toys but plays with just 12 daily.

Purewal (2015:1 of 1) opines, for example, that the majority of those who purchase new smart phones do not really 'need' them, as the reasons they provide, such as 'my phone is too old' when the phone is only two years old, the need for a bigger or a smaller screen phone, 'I have run out of storage space' and 'the new phones look pretty', only reflect 'want' and not 'need'.

In Africa, Kenya in particular, consumerism, or stated differently, the frivolous and unrestrained accumulation of 'stuff', manifested in the ever mushrooming mega retail stores, supported by advertising agencies and media outlets, rapidly replace churches and mosques in shaping Kenya's (and by extension Africa's) worldview(s) on priorities, values and needs. Shikwati (2013:1 of 1) makes the following eyeopening and informative observations, namely, that it is in Kenya that one can walk from a New York type mega retail store, 'straight into a village infested with jiggers.' Shikwati bemoans Kenya's consumerism model that continues to produce a society that pursues false needs and is trapped in false priorities. According to Shikwati, a middle-class Kenyan is adorned with imported shoes, soaks, pants, watch, body lotion, drives an imported car running on imported fuel, drinks imported fruit juice, beer, sleeps on imported beddings and the poor and under-privileged aspire to join this status. The surge in retail outlets without investment in factories that should provide products for both local and external markets is likely to imprison the country in perpetual poverty and insecurity, Shikwati observes. Supermarkets are modernday Kenya's monuments of consumption that reflect largely a pattern of a country's so-called middle class settlements located in cities and major urban areas. Shikwati estimates that there are over 230 supermarkets in Kenya, which have already displaced over 90000 small shops. Mega shopping malls are estimated to be over 20, concentrated mainly in Nairobi, Mombasa, Kisumu, Nakuru and Eldoret.

According to Kiprono (2012:1 of 1) and Rubadiri (2012:1 of 1), Kenya's youth, aged between 16 and 24 who are about seven million, spend Ksh64 billion annually on clothes and other accessories. Among them, $32 \%$ to $39 \%$ own or aspire 
to own an iPhone or a BlackBerry phone. Kenya is among 10 other African countries, namely, Algeria, Angola, Egypt, Morocco, Nigeria, South Africa, Sudan and Tunisia, whose youth accounted for $81 \%$ of Africa's private consumption in 2011 (Hattingh et al. 2012:4-9; Shikwati 2013:1 of 1). The continent's youth are brand conscious, seek products and stores that reflect the 'right image', follow latest fashion and trends and are keen to try new things.

Shikwati (2013:1 of 1) laments the rise of consumerism in Kenya, which has seen growth in lottery gratification where individuals seek to leapfrog their economic status devoid of hard work and investment. Shikwati rightly regrets a sacrificing of a savings culture, which should be prioritised as a strategy to buffer individuals and the nation in times of hardships. As such, a growing number of Kenyans have gradually become focused on short-term gratification at the expense of investments in skills and knowledge to improve productivity and not consumerism. Sadly, institutions such as family and community are losing out as the nation's people scramble for relevance in modern showy trend.

Although in some instances consumption (consumerism?) is an individual and private affair, cumulatively evaluated, it forces one to take a keen interest in where the working class in Kenya invest, or where, for example, a Kalenjin who sells off their land in Nandi, Uasin Gishu or Trans-Nzoia counties invests his or her money. Arguably, growth in gated housing and private security firms in Eldoret and in other major Kenyan towns could be indicative of consumerism gone awry, as short term goals drive the many poor Kenyans into criminal activities. For Shikwati (2013:1 of 1), conspicuous consumption among the privileged few has become a breeding ground for a class of the excluded, ready to pounce on those who flaunt their wealth.

The challenge of consumerism raises a number of questions, namely, should Kenyans really celebrate the number of graduates churned out per year, without any patents, which could be transformed into commercial enterprises per year? Shouldn't the nation's legislative infrastructure be geared towards putting wind into the sails of local productivity through incentives towards intellectual growth, innovation and logistics? Shouldn't the nation be positioning itself as a net producer of solutions to both its challenges and those facing the rest of the continent? Consumerism is standing in the way of Kenya's greatness. The rise of consumerism in the context of Kenya's unending poverty challenges everyone, churches in particular, to seek alternatives to wanton material accumulation, founded on the belief that one's meaning and completeness depends on material accumulation.

\section{Factors motivating consumerism}

This article is premised on the idea that people would be better off and much happier if they consumed less and not more. The question, however, is why do people embrace consumerism if indeed they would be better off with a less hyper consumerist lifestyle? Is there a systematic consumption bias in the decisions that people make? If so, would people make different choices, consume less and in the end live better quality lives, if such consumption biases were eliminated? There is nothing intrinsically wrong with shopping and consuming as such, however, there has to be a problem with systems that shape people's preferences and choices excessively in favour of consumption over other values. What then, are some of the processes at play in contemporary societies that foster a strong consumerist culture? Some of the factors that foster consumerism include the following:

\section{Advertising}

Marketing is a key mechanism that fosters a culture that underwrites consumerism. Advertising on television, radio, billboards, Internet, newspapers, and magazines abound (Katz 2014:1-34; Jin \& Lutz 2013:345; Wallace \& Wallace 2001:94-96). Companies and corporations spend large sums of money for 'naming rights' of public facilities, for example, in order to keep their brands in the minds of people.

Marketers devise sophisticated means to reach the public and to shape people's preferences (Deborah et al. 2015:7-8; Akyol 2014:151-158). The means include intense advertising directed at, for example, young children, where in some instances, children are taught how to nag at their parents for a given product.

According to Soriano et al. (2015:1-4,13-15), advertisements do much more than merely transmit information into displaying and even reinforcing certain values, by constantly affirming an association between happiness and the use of a product, between success in life and buying more 'stuff', between sexual attractiveness and particular forms of consumption. Such associations have become the taken-forgranted way of life, which for many, is from childhood. In this way, advertisements make a life that is heavily oriented towards consumerism seem normal and natural.

A few years ago, mainly people very much like themselves within their immediate communities for example, defined consumption patterns of many people, particularly in Kenya. Presently, however, consumption norms and patterns are shaped largely by images that people see and hear in the mass media. A typical commercial advertisement during a soccer match, for example, shows giant flat screen television sets that are not really modest by any standards. The homes and apartments in most sitcoms are very fashionable ones in buildings in very expensive suburbs. The result, arguably, is a realisation of a large gap between what people can afford and what they 'feel' they should consume.

\section{Credit cards}

Consumerism fosters a desire to consume 'stuff' right now. Any delayed gratification of careful savings stands contrary. An alternative to a savings culture in which people can easily borrow money to buy 'stuff' now and pay back the loan over 
a longer period is accomplished by consumer credit and nothing fuels consumer credit more than the credit card.

It is no secret (Gardon 2016:1 of 1; Soll et al. 2013:66-69, 80) that the credit card industry has grown exponentially by making consumer credit available to nearly everyone with minimal screening. The credit card companies continue to promote consumer debt by advertising the use of their cards, showing how pleasant life can be when one uses a credit card to buy what one desires. The credit card companies also send unsolicited cards. They do the aforementioned because they make money off each transaction, as merchants pay fees to the credit card companies. They make most of their money off late fees and interest payments. They are eager to get people to use credit cards to buy 'stuff' that is more expensive than what they can afford, as the revenue of the credit card issuer comes from interest on unpaid balances and penalty fees.

\section{Increased inequality}

The notion of inequality, which may be described differently as the economic distance between those on the top and those at the bottom, is arguably having an impact on the consumption norms of those in the middle and those at the bottom (the poor). Stated differently, some forms of consumerism involve 'positional goods', the subjective value of which is heavily dependent on comparison with what others consume. As such, increased inequality tends to fuel a 'positional arms race' in which, much like the metaphor, in which 'everyone stands up to get a view, yet no one sees any better than before' (Frank 2009:12; Frank 2007:5, 78-86).

There seems to exist a psychological process in which the satisfaction that one derives from owning 'stuff' depends in part on one's perception of what others own. This may be further complicated by the way in which other 'important interests' become linked to the 'stuff' already owned. For example, access of children to good schools in some situations, is dependent to an extent on the neighbourhood in which one lives. As inequality increases, so do inequalities across neighbourhoods increase, also increasing inequalities in schooling. This may increase pressure on some middle class and much poorer people to try to live in more expensive neighbourhoods, which have expensive housing, not mainly because of a consumption desire for big houses, but in order to move up the neighbourhood hierarchy and therefore gain access to better schools. Increased inequality tends to lead to increased pressure for positional consumption, the result of which is increased debt.

\section{Erosion of the quality of public amenities}

It is advanced (Njue \& Muthaa 2015:162-169; Chen et al. 2014:3-7; Brunner \& Sonstelie 2006:20-24) that a decline in the provision of quality public goods and services has a resultant abandonment effect of those amenities by the public and can become a motivator for consumerism. In communities where public amenities such as good schools, good libraries, well constructed and attractive public swimming pools, good public transport, are well maintained and kept in excellent conditions and serviced well and regularly, the pressure for private consumption is low. Erosion and mismanagement of public goods and services makes private substitutes more attractive, for instance, private schools become more attractive when public schools deteriorate, gated communities become more attractive when public safety and policing deteriorate, private swimming clubs and private home pools become attractive because of the deterioration of public recreational facilities, private cars become more attractive and more essential because of the deterioration of public transport systems.

\section{Profit maximisation strategies}

The nature of various contemporary economies demands that people buy 'stuff'. Spending money is essential for the health of national economies. People are therefore encouraged to spend (Grant 2016:165-286; Nugent \& Werema 2015:4-9; Whittington 2013:1-22). It is advanced that if large numbers of people within a given country were to opt for a lifestyle of voluntary simplicity by rejecting consumerism, the economy would face serious difficulties. Consumerism is therefore not simply one of the many possible individual lifestyles; it is a built-in tendency within economies, especially capitalist economies. Profit maximisation is a fundamental process that generates consumerism in capitalist economies.

Consumption bias inherent in capitalist economies is revealed in times of economic crises, when governments attempt to stimulate the economy by encouraging people to consume more, by either reducing taxes, reducing interest rates so that borrowing is cheaper and in some instances, by directly giving people money to spend. Invigoration of mass consumerism is a condition inbuilt in capitalist economies.

The forgone, namely, advertising, credit cards, increased inequality, erosion of the quality of public amenities and profit maximisation strategies, are just but a few examples of the many factors motivating consumerism. Consumerism continues to wrap its many tentacles around many of us. Consumerism continues to be an all-pervasive theme in many of our contemporary cultures. It is becoming a way of life and a judgement about what the best of life is. It is seeping into most parts of many people's lives, whether they are aware of it or not and consumerism continues to profoundly affect many.

\section{The problem with consumerism}

The kinds of consumerism that dominate many of our contemporary cultures have a number of unpleasant and even potentially dangerous features.

\section{Consumerism does not meet needs}

Consumerism creates impossible aspirations by making it a logical impossibility that a consumer can be truly happy. 
The very idea behind consumerism is the creation of new 'needs' and making people consume more, resulting in a constant chasing (Docwra 2009:19-22; Bartholomew \& Moritz 2000:9). Consumerism does not aim at meeting real needs and interests, but at generating profit. Although consumerism involves a consumption of some basic needs such as food and shelter, it fails to meet other non-market needs, such as companionship, time for reflection, spirituality, security, intellectual development and joy in children. Although some products are linked through advertising to a life lived in fullness, consumerism represents a sad aspect of manipulative power. A culture of consumerism is in conflict with well-being aims, such as poverty reduction and sustainable living. Manipulative power flexed through advertising makes it hard to see inconsistencies in consumerism in order to pursue alternatives. The very countenance of consumerism is satisfaction never actually being achieved.

\section{Consumerism imposes limits on choices and lives}

A fuller life is one in which people can make real choices among genuine life-affirming options. Consumerism in its broadest sense is an advancement of a view of what a 'good life' is, namely, the acquisition and accumulation of goods. It is a view on how life MUST be lived. It stands against a life lived in simplicity, with a focus on time and people rather than material possessions (Sen 1999:15, 19, 285, 291; Docwra 2009:23-25). Genuine choices and options are a key feature of a good life, however, consumerism is a restriction of a people's ability to an alternative life of choices and freedoms. The power of advertising within consumerism is a powerful influential force in many contemporary cultures.

\section{Consumerism impacts worldviews and people's characters}

Consumerism contributes significantly to how people perceive their world. It influences where and how people spend much of their time, energy and resources. Since it is about purchasing 'another' product, less time and enthusiasm is placed on broadening one's horizons in terms of learning about resource availability and the capacity of the planet to hold the waste generated due to consumerism (Docwra 2009:25-26; Wilkens \& Sanford 2009:13-16).

Consumerism moulds people's characters into self-interest and a pursuit of interests other than those for the common good. Those trapped by consumerism struggle to have an interest in people and human values. Stated differently, those trapped in a lifestyle of consumerism have diminished social involvement, tend to be preoccupied with 'self' and are overly competitive (Bauer, Wilkie \& Kim 2012:517, 522). A materialist mindset orients an individual to competitive concerns about relative standing. It contributes to feelings of anxiety and dissatisfaction and disinclination to trust other people and engage with them in deep, collaborative ways.

\section{Consumerism is unsustainable}

The earth's population is rapidly growing, and has a finite set of natural resources for the earth's population to consume. Humanity has probably already used more than half of the planet's known bio-capacity, living beyond the planet's limits. The ever increasing levels of consumption demanded by consumerism cannot be sustained without major consequences (Holt 2012:236, 254; Docwra 2009:26).

The forgone discussion has highlighted some problems linked to consumerism, namely, that consumerism does not meet real human needs, imposes limits on choices and lives, impacts on worldviews and people's characters, and that it is unsustainable. What is urgently required is precisely the opposite of consumerism. We need a framework, a perspective that can enable us to respond to the challenge of consumerism, particularly within contexts of poverty, for which the article now turns to, after a discussion on an interplay between consumerism and poverty.

\section{An interplay between consumerism and poverty}

Consumerism in its various manifestations is a key contributing factor to the ravaging socio-economic challenges of modern life. The gap between the so-called 'haves' and the 'have-nots' continues to widen and may worsen unless there is a drastic response. On the fringes of utter affluence lie dehumanising poverty, hopelessness and despair. Poverty continues to affect billions globally.

According to the World Bank Group (2016:ix-xvii, 27-45, 61) extreme poverty remains unacceptably high, becoming more concentrated in sub-Saharan Africa and South Asia. Despite recent solid development gains, progress has been uneven and significant work remains. Sub-Saharan Africa, East Asia and Pacific and South Asia account for 95\% of global poverty. The share of sub-Saharan Africa in global poverty has risen to $43 \%$ alongside a slower pace of poverty reduction amid rapid population growth. The World Bank Group report further notes that three key challenges stand out, namely, the depth of remaining poverty, the unevenness in shared prosperity and the persistent disparities in non-income dimensions of development. The report advises that non-income disparities, such as limited access to quality education and health services pose a bottleneck to sustained poverty reduction and shared prosperity.

According to the World Bank Group (2015:1 of 1), Bigsten et al. (2014:20) and the Rural Poverty Portal (2014:1 of 2), Kenya's development challenges include poverty, inequality and the vulnerability of the economy to both internal and external shocks. Irrespective of the data type and measurement method, poverty and inequality remain high in Kenya. The structure of the economy has not changed enough to make a real dent in poverty levels. The country remains an agrarian economy, the capital and labour ratio is still declining and the manufacturing sector is small and stagnant, 
with few jobs created for the rapidly growing labour force. Bigsten et al. advise that high growth and poverty reduction can only be achieved through productivity-enhancing transformation of the economy. It is lamentable that half of the country's population live below the poverty line, unable to meet their daily nutritional requirements. Over four million people required food assistance in 2010 and 2011 due to frequent intense droughts and floods.

Consumerism is structured around consumption as a 'normal life' and the bonds of consumption are considered to be the most significant links that unify people. Ardent consumerists are therefore perceived as the respected, the hardworking and the aspiring members of the consumerist societies (Hamilton et al. 2014:1834). For the poor to attain some form of dignity and self-determination and to be accepted within such cultures, they have to be seen to be consumers.

Social exclusion broadly refers to a rupture of social bonds (Hamilton et al. 2014:1838). Poverty can result from or contribute to exclusion from circles or networks and support system requisite to meaningful living. For some of those living in poverty, consumerism becomes a way of ensuring that they are socially included. The purchase of a new expensive fashion dress, phone, television, or house, even when one cannot really afford it, becomes a means to ensure that one is part of a community. Responses to the excluding effects of poverty can vary and the resources people bring to manage exclusion are diverse, including getting into impoverishing debt in order to be part of a community.

Poverty is vulnerability. Experiences of vulnerability influence consumption practices (Hamilton et al. 2014:1843). Consumerism is arguably one of the ways in which those who live in poverty conceal their vulnerability and avoid the stigma of appearing vulnerable before members of one's own 'beloved' community.

Through advertising, markets link consumerism with pleasure. Owing to the fact that pleasure and poverty are often seen as antithetic, the poor are assumed to be unable to afford and experience pleasure (Hamilton et al. 2014:843). In a culture that emphasises pleasure through consumption, the poor are likely to experience frustration and temptation. The poor get into consumption to avoid feelings of unhappiness from the privatisation of pleasure and also to escape the misery and stigma of poverty.

On the other side of the spectrum from pleasure is contentment. Contentment involves a focus on energising life's forces in the face of perceived 'lack' in one's life. Contentment may be present or may be sought after in spite of very unhappy circumstances (Hamilton et al. 2014:1845). As such, contentment is commendable and praiseworthy. However, consumerism demeans contentment as an attitude that represents being stagnant or having an unhealthy acceptance or resignation to a 'bad' life situation. Some poor people resort to consumerism in order to be seen to be making attempts at breaking the yoke of a 'bad' life. Sadly, however, responding in this manner only leads to deeper frustrations, humiliations, more debt and ill-being. In the words of
Hamilton et al. (2014:1845), 'for many experiencing poverty, contentment in life seems out of one's grasp.'

The forgone discussion demonstrates how consumerism can trap the poor in poverty and drive them into deeper depths of poverty. Consumerism from this perspective is a poverty trap. For Ndukwe (2013:6), consumerism is the backbone of poverty, which eats deep into the fabric of human social order. It makes a mockery of human identity and as such there is a need for a theological vision for reforming economies.

Although various responses to consumerism have been advanced, this article, however, investigates how the life and works of Leo Tolstoy can assist churches, particularly the Africa Inland Church in Kenya, to respond meaningfully and adequately to consumerism in context of poverty.

\section{The person and works of Leo Tolstoy}

Leo Tolstoy was born in the Tula province of Russia on 9 November 1828, the youngest of four boys. His mother, Princess Volkonskaya died in 1830 and his father's cousin took over their care. His father, Count Nikolay Tolstoy died in 1837, and their aunt was appointed as their legal guardian, however, when their aunt died, they moved in with their second aunt in Kozan, Russia. Tolstoy had his primary education at home under French and German tutors. Later in 1843, he enrolled at the University of Kozan, where he studied Oriental languages, but failed to excel as a student. He left the University of Kozan in 1847 without a qualification and returned to his parent's estate and tried farming, but also failed. Through the influence of one of his older brothers, he joined the Russian military and transferred to Sevastopol in the Ukraine, where he fought in the Crimean war until August 1855. Between 1852 and his death on 20 November 1910, Tolstoy contributed to the publication of his twelve novels, twelve short stories, two drama plays, six essays and three autobiographical writings. Tolstoy is mainly known for his two books, War and Peace and Anna Karenina which depict realistic Russian life. He is however described as a moral philosopher for his ideas in nonviolent resistance through his work The Kingdom of God is within you which is claimed to have influenced Mahatma Gandhi and Martin Luther King (Morson 2015:1 of 1; Famous Authors 2012:1 of 1; Townsend 1998:63-67).

In instances where one's completeness is dependent on consumerism, life becomes 'hot air', vanity and a chasing after the wind, comparable to that described in the Christian Bible, Ecclesiastes 1:1-4 ${ }^{1} ; 2: 11^{2}, 22^{3}$ and 5:10. ${ }^{4}$ Popova (2014:1 of 1) provides a very helpful link between Tolstoy and the pursuit for meaning in life within a meaningless

1.The words of the Teacher, son of David, king in Jerusalem: "Meaningless! Meaningless!" says the Teacher. "Utterly meaningless! Everything is meaningless." What do people gain from all their labors at which they toil under the sun? Generations come and generations go, but the earth remains forever' (NIV).

2.'Yet when I surveyed all that my hands had done and what I had toiled to achieve, everything was meaningless, a chasing after the wind; nothing was gained under the sun' (NIV).

3.'What do people get for all the toil and anxious striving with which they labor under the sun?' (NIV).

4.'Whoever loves money never has enough; whoever loves wealth is never satisfied with their income. This too is meaningless' (NIV). 
materialistic world. After turning 50, Tolstoy sank into deep depression despite amassing a sizeable amount of wealth: a large estate, a promise of eternal literary fame, a wife with fourteen children and good health for his age. On the brink of suicide, Tolstoy turned to the world's great religions and philosophical traditions in search for an answer to his quest for the meaning of life. His questions 'What is the meaning of life beyond time, cause, and space?' and 'What is the meaning of life within time, cause, and space?', made him to turn to faith. His discovery, Popava writes, was that faith 'gives to the finite existence of man [humanity] infinite meaning, a meaning not destroyed by suffering, deprivation, or death.' The more he examined the substance of faith, the more he found glaring disconnect between it and the teachings of the Christian church of his time and the practices of the wealthy. In despair, he turned to the peasants of his time, which for him became a bridge between the finite and the infinite, and as paragons of spiritual salvation. Tolstoy's observation was that the peasants knew the meaning of life and death, laboured quietly, endured deprivation and sufferings, and lived and died, seeing in their situations not vanity but good. Tolstoy's conclusion was that, to live a life of meaning, one had to stop living as a parasite but live real, taking the meaning given to life by real humanity and merging oneself into that life.

One of Tolstoy's greatest gifts to humanity was his addiction to the meaning of life. He never ceased to ask himself what was the point of all his fame and wealth. After immersing himself in the writings of the German philosopher Schopenhauer, Buddhist texts and the Bible, he adopted a revolutionary brand of Christianity, which rejected organised religion and turned towards a life of spiritual and material austerity. Tolstoy adopted the simple life, described variously as simple living or plain living. Tolstoy also adopted the hard labour of the Russian peasantry. He is known for having inspired the creation of communities for simple life (Krznaric 2013:1 of 1; Shi 2001:180).

In contemporary discourse, simple living, according to Shi (2001:3-7), has characterised such activities as the back-tothe-land movement, art and craft revivals, organic gardening, environmental conservation and recycling, anti-nuclear demonstrations, urban cooperatives, wilderness expeditions and consumer frugality. From the days of Tolstoy, the precise meaning of simple living has represented a shifting cluster of ideas, sentiments and activities, which have included hostility towards luxury and a suspicion of riches, a reverence for rural over urban ways of life and work, a desire for personal self-reliance through frugality and diligence, a nostalgia for the past and a scepticism towards the claims for conscientious rather than conspicuous consumption and an aesthetic taste for the plain and functional. Over the years, there has been a varied emphasis placed on these attitudes, representing a wide spectrum of motives and methods. The common denominator, however, is the core assumption that the making of money and the accumulation of things should not be allowed to smother the purity of the soul, the life of the mind, the cohesion of the family, or the common good. At the core, simple life is an approach to living that self-consciously subordinates the material to the ideal.

In its varied manifestation, simple living runs through the Christian scriptures (Shi 2001:3-7). It is expressed in the living habits of tent dwellers of Abraham's time, to the strictures of the prophets against the evils of material excessiveness. Jesus' life represented a protest against excessiveness and warned against the deceitfulness of riches, noting that superfluous wealth too easily leads to hardness of heart towards one's fellows and deadness of heart towards God. Jesus urged his followers to seek their treasures in heaven, rather than on earth.

For Tolstoy, simple living was about simplifying life in order to engage in a variety of enriching pursuits, such as religious devotion, artistic creation, revolutionary politics, humanitarian service or ecological activism (Shi 2001:3-7). Individuals and groups that reflect both the variety and unity of simple living, demonstrate a persistent desire to elevate life above the material and the mundane. Simple living is a voluntary lifestyle of simplicity, reducing possession with an emphasis on what one has over want. Tolstoy found answers to his quest for life's meaning in the midst of the meaninglessness of his wealth and fame, through a study of the hard labour of the Russian peasantry. What is curious, therefore, is what it was in the hard labour of the Russian peasantry that provided an answer to Tolstoy's quests and how peasant hard labour could be a guide to life's meaning in today's consumerism, particularly in contexts of poverty.

\section{Peasant hard labour as a guide to life's meaning}

How could Tolstoy turn to peasants in their peasantry and find answers to his quest for life's meaning? What is a peasant and what is peasantry? Descriptions of 'peasant' and 'peasantry' are complicated and contentious. Such is the case, because definitions for human groups arise for different purposes, such as social control, legal protection, social scientific analysis, collective action and colloquial descriptions. Even though normative definitions appear to fix an object in a timeless way, in practice definitions change over time (Edelman 2013:2).

There is a historic understanding of what is meant by a peasant emerging from societies where peasants constituted estatelike, caste-like, corporate or subordinate groups, characterised by specific restrictions on geographical or social mobility, limited rights and obligations to provide services and perform duties for superordinate groups. Peasants included the rural poor, rural residents, agricultural labourers and the so-called common or simple people. In Russia, for example, they constituted a social estate, bound to landlords with no rights to geographical mobility (Edelman 2013:3; Shanin 1972:19). In addition to the historic understanding, there are recent social scientific efforts that theorise the notions of 
'peasant' and 'peasantry', that, for example, locate 'peasant farming' on a continuum with 'entrepreneurial farming'. Within this understanding, key features of peasant conditions include minimising monetary costs, crop diversification to reduce economic and environmental risks, nurturing cooperative relations that provide an alternative to monetary relations and market exchange, and a struggle for autonomy, which includes non-monetary forms of attaining inputs and labour (Edelman 2013:9; Van der Ploeg 2008:47-49; Weis 2007:25). Apart from the historic and social scientific descriptions, is the activist definition. In line with the rise of social movements, peasants have received heightened global political profile and the 'peasant' label has newfound contemporary resonance (Edelman 2013:9-11; Borras Jr. et al. 2008:177-185). The agenda of activists is the desire to attract a maximum number of adherents and allies by casting a wider net, while also bounding their movements so as to exclude sectors opposed to their objectives. As such, 'peasants' for activists generally include national organisations that represent varied constituencies for rural workers and small and medium-sized cultivators in developing countries, to small and medium-sized commercial farmers in the developed countries. This rendering of the term brings in diverse rural livelihoods, which strictly speaking are not agricultural, such as fishing, pastoralism, artisan craft production and hunters and gatherers.

The foregone descriptions highlight the place and priority of peasantry as a simple life metaphor, which is here suggested as an antidote to a mistaken belief that one's well-being and completeness depends on material consumption.

When Tolstoy turned to the peasants of his time, he saw a people whose everyday lives and work were largely to the benefit of others. Those peasants had to perform duties largely for the pleasure and enjoyment of the superordinate. They woke up each day to serve others (other-focused). The notion of being other-focused is spoken highly of in the Christian scriptures, Philippians 2:3-4. ${ }^{5}$ It is a Christian virtue to esteem others better than oneself, not because it is the natural thing to do, but because it is a mark of true Christian greatness. The peasants were under the obligation, however, to work and provide services primarily for others and secondarily for themselves. Tolstoy's observation was that the peasants were happier and seemed to know life's meaning nonetheless.

The other emphasis highlighted, is the struggle for autonomy inherent in peasantry, manifesting in the diversification and reduction of economic and environmental risks. Inbuilt into peasant ways of life is the nurturing of alternative relations, which are not reliant on consumption, but seek to minimise monetary costs. Contemporary forms of consumerism are a cause for economic and environmental challenges experienced by many. 5.'Do nothing out of selfish ambition or vain conceit. Rather, in humility value others
above yourselves, not looking to your own interests but each of you to the interests of the others' (NIV)
Peasantry goes beyond agriculture to other forms of livelihoods, which are not party to the demands of multinationals, which thrive on consumption and more consumption.

The above described aspects of peasantry, which place emphasis on the simplicity of life in the form of hard work, the struggle for autonomy, and the embracing of diverse livelihoods, expressed through Tolstoy's discovery, can be an antidote to relentless and meaningless of life that manifests in consumerism.

\section{Implications for the Africa Inland Church - Kenya}

Various disingenuous ways to exit poverty continue to play out in Kenya's public and private life, manifesting in corruption, trafficking, ethnic-based conflicts, gangsterism and gender-based conflicts and child labour. Kenya's corruption plays out in various ways, such as in the paying or demanding of bribes for services, land grabbing, tax evasion, importation of unlicensed goods and in government procurement and tenders (McConnell 2015:1 of 1). Drug and human trafficking is on the increase. A few ships have lately been destroyed off the cost of Kenya after they were discovered to have been used to import huge amounts of drugs into the country. Kenya continues to be a source, a destination and a transit point for human trafficking (Ongiri 2015:1 of 1; Walloga 2014:1 of 1). Ethnic-based conflict was the hallmark in 2007 and 2008, when unresolved land issues flared up after the elections. Various communities continue to fight for water and grass for their animals (Gosh 2013:1 of 1). Groups such as the Mungiki and other gangsters and gender-based conflicts are a never-ending menace, particularly in the urban areas (Odongo \& Ng'ethe 2015:1 of $1)$. High rates of child labour are largely blamed on poverty, among other factors (Chigiti 2012:1 of 1).

The forgone dishonourable ways to exit poverty and get material wealth quickly presents a challenge and an opportunity for the Africa Inland Church. As earlier mentioned, consumerism affects both the 'haves' and the 'have-nots' and the analogy of peasantry as a pointer to a fuller and richer life and as a framework against consumerism can be very helpful to the church.

Genuine hard work is valuable in its own right. It is even more valuable among the poor as it brings dignity and can contribute significantly to transformative solutions to poverty, crime, violence and substance abuse. By teaching its members the values of hard work, advocating fair pay for work done, including education of how to wisely use or save one's income, the church becomes a means of grace to the poor who are pulled on the one side by forces of poverty and the false claims of consumerism on the other.

The church will have to encourage and facilitate self-reliance as a means of survival among the poor. This includes the 
formation and promotion of local solidarity groups and the creation of support systems, such as farming groups, and granting or negotiating for affordable loans for individuals and groups in order to pursue individual or group interests. Self-reliance as a response to poverty, equally speaks to the manipulation by multinationals that use advertising of a better life linked to, not to hard work or self-reliance, but consumption.

The church has a noticeable presence among the nomadic communities in Northern Kenya and also among the Maa communities in the Rift Valley. These communities are mainly nomadic pastoralists. A facilitation of diversification of their livelihoods can be key to their survival against drought. By modelling flexibility, the church has to suggest context-specific and practical alternatives in the face of high risks, absent markets, poor infrastructure and declining land size.

\section{Conclusion}

This paper has discussed the place and priority of the simple living as seen from the perspective of Leo Tolstoy. A wealthy prosperous Tolstoy had succumbed to depression in spite of his material possessions and literary fame. After looking for answers from various religions and philosophies, Tolstoy turned to a study of the peasants of his time for an answer to his quest for the meaning of life.

Consumerism is a global and a local challenge. One of the features of consumerism is the promise of a richer and fuller life resulting from material accumulation. In contexts of poverty, the poor are equally trapped in deprivation by consumerism.

Three pillars of Tolstoy's simple living are suggested as a framework for the Africa Inland Church's response to the challenge of consumerism in the context of poverty in Kenya. The three pillars are, hard work, self reliance and diversification of livelihoods.

More studies are required in future to provide a detailed breakdown on how individual local churches could adopt these pillars to respond to contextual challenges brought about by consumerism in different specific contexts of poverty in Kenya.

\section{Acknowledgements Competing interests}

The author declares that he has no financial or personal relationships which may have inappropriately influenced him in writing this article.

\section{References}

Aaker, D.A. \& Day, G.S., (eds.), 1971, Consumerism: Search for the consumer interest, The Free Press, New York.

Akyol, Ş., 2014, 'Factors affecting the consumer preference in buying technological products', The Business \& Management Review 5(1), 151-158.
Bartholomew, C. \& Moritz, T. (eds.), 2000, Christ and consumerism: Critical reflections on the spirit of our age, Paternoster Press, Cumbria.

Bauer, M.A., Wilkie, J.E.B. \& Kim, J.K., 2012, 'Cuing consumerism: Situations materialism undermines personal and social well-being', Psychological Science 23(5), 517-523. $\mathrm{http}: / / d x$.doi.org/10.1177/0956797611429579

Bigsten, A., Manda, D.K., Mwabu, G. \& Wambugu, A., 2014, 'Income, Inequality, and Poverty in Kenya', viewed on 03 March 2016, from http://erepository.uonbi.ac.ke/ bitstream/handle/11295/80559/Bigsten_Incomes $\% 2 \mathrm{c} \% 20$ inequality $\% 2 \mathrm{c} \% 20$ and $\% 20$ poverty $\% 20$ in $\% 20$ Kenya $\% 3 a \% 20 \mathrm{~A} \% 20$ long-term $\% 20$ perspective. pdf? sequence=1\&isAllowed=y

Borras Jr., S.M., Edelman, M. \& Kay, C., 2008, 'Transitional Agrarian Movements: Origins and Politics, Campaigns and Impact', Journal of Agrarian Change 8(2-3), 169-204.

Brobeck, S., 1990, The modern consumer movement: References and resources, G.K. Hall \& Co., Boston, MA.

Brunner, E.J. \& Sonstelie, J., 2006, 'California's school finance reform: An experiment in fiscal federalism', Economics Working Papers 4(1), 1-40, paper 200609, viewed 1 March 2016, from http://digitalcommons.uconn.edu/econ_wpapers/200609

Chen, A., Dutta, A. \& Maina, T., 2014, 'Assessing the Quality of Primary Healthcare Services in Kenya', viewed on 01 March 2016, from http://pdf.usaid.gov/pdf_ docs/pa00k453.pdf

Chigti, J., 2012, 'Kenya: Child labour is a human rights violation', The Star, 10 October, viewed 11 March 2016, from http://allafrica.com/stories/201210161194.html

Cohen, S., 1967, 'Furness role has yet to unfold but old order in consumerism is changing', Advertising Age, 13 March, p. 4.

Coontz, S., 1992, The Way We Never Were, Basic Books, New York.

Deborah, A., Nelson, O. \& Joseph, K., 2015, 'Advert exposure on consumer purchase decisions: An empirical study on MTN Nigeria', Journal of Accounting and Auditing: Research \& Practice Article ID 435369. http://dx.doi.org/10.5171/2015.435369, viewed 1 March 2016, from http://www.ibimapublishing.com/journals/
JAARP/2015/435369/435369.pdf

De Graaf, J., Wann, D. \& Naylor, T.H., 2014, Affluenza: How over-consumption is killing us - And how to fight back, 3rd edn., Berrett-Koehler Publishers, San Francisco, CA.

Docwra, R., 2009, 'The problem with consumerism', viewed 02 March 2016, from http://www.lifesquared.org.uk/system/files/Consumerism\%20download_1.pdf

Dwyer, R.E., 2007, 'Expanding Homes and Increasing Inequality: U.S. Housing Development and the Residential Segregation of the Affluent', Social Problems 54 (1), 23-46. http://dx.doi.org/10.1525/sp.2007.54.1.23

Edelman, M., 2013, 'What is a peasant? What are peasantries? A brief paper on issues of definition', viewed 10 March 2016, from http://www.ohchr.org/Documents/ HRBodies/HRCouncil/WGPleasants/Edelman.pdf

Famous Authors, 2012, 'Leo Tolstoy', viewed 03 March 2016, from http://www. famousauthors.org/leo-tolstoy

Frank, R.H., 2007, Falling Behind: How Rising Inequality Harms the Middle Class, University of California Press, Berkeley.

Frank, R.H., 2009, 'Post-consumer prosperity: finding new opportunities among the economic wreckage', The American Prospect 20(3), 12-15.

Gardon, M., 2016, 'How credit card companies make money', viewed 01 March 2016 from http://www.thesimpledollar.com/how-credit-card-companies-make-money/

Garman, E.T., 1991, Consumer economic issues in America, Houghton Mifflin, Boston, MA.

Gosh, S., 2013, 'What is fuelling Kenya's ethnic violence?', Aljazeera (17 January), viewed 11 March 2016, from http://www.aljazeera.com/programmes/insidestory/ 2013/01/2013116142546193334.html

Goulden, C. \& D'Arcy, C., 2014, 'A Definition of Poverty', viewed 24 February 2016 from http://citeseerx.ist.psu.edu/viewdoc/download?doi=10.1.1.695.3141\&rep= rep1\&type=pdf

Grant, R., 2016, Contemporary strategy analysis, 9th edn., John Wiley \& Sons, Sussex. Greer, P., 1944, 'Consumers Find Themselves', The New Republic, 4 September, 274-276. Hagenaars, A.J.M., 1986, The perception of poverty, Elsevier Science Publishers B.V., Amsterdam.

Hamilton, K., Piacentini, M.G., Banister, E., Barrios, A., Blocker, C.P., Coleman, C.A., Ekici, A., Gorge, H., Hutton, M., Passerard, F. \& Saatcioglu, B., 2014, 'Poverty in consumer culture: Towards a transformative social representation, Journal of 257X.2014.967929

Hattingh, D., Russo, B., Sun-Basorun, A. \& Van Wamelen, A., 2012, 'The rise of the African consumer', viewed 29 February 2016, from http://www.mckinsey.com/ industries/retail/our-insights/the-rise-of-the-african-consumer

Holt, D.B., 2012, 'Constructing Sustainable Consumption from Ethical Values to the Cultural Transformation of Unsustainable Markets', The Annals of the American Academy of Political and Social Sciences 644(1), 236-255. http://dx.doi. org/10.1177/0002716212453260

Jin, H.S. \& Lutz, R.J., 2013, 'The typicality and accessibility of consumer attitudes towards television advertising: Implications for the measurement of attitudes
towards advertising in general', Journal of Advertising 42(4), 343-357. http:// towards advertising in general, Journal of $A d$
dx.doi.org/10.1080/00913367.2013.803184

Katz, H., 2014, The media handbook: A complete guide to advertising media selection, planning, research, and buying, 5th edn., Routladge, London.

Kiprono, E., 2012, 'Kenya youth spending whooping ksh. 64 Billion annually' viewed on 29 February 2016, from http://fenesi.com/kenya-youth-spending-whoopingksh-64-billion-annually/

Korayan, K. \& Mashhour, N., 2014, 'Poverty in secular and Islamic economics; conceptualisation and poverty alleviation policy, with reference to Egypt', Topics in Middle Eastern and African Economics 16(1), 1-16, viewed 24 February 2016, from http://www.luc.edu/orgs/meea/volume16/pdfs/Korayem-Mashhour.pdf 
Krznaric, R., 2013, 'Six life lessons from Leo Tolstoy', viewed 09 March 2016, from http://www.powells.com/post/original-essays/six-life-lessons-from-leo-tolstoy

Lawlor, E., 1988, Individual choice and higher growth, Commission of the European Communities, Brussels.

McConnell, T., 2015, 'Corruption in Kenya "worse that ever" says veteran campaigner', viewed 11 March 2016, from http://www.businessinsider.com/afp-corruption-inkenya-worse-than-ever-says-veteran-campaigner-2015-8

Morson, G.S., 2015, 'Leo Tolstoy', Encyclopaedia Britannica, viewed 06 March 2016 from http://global.britannica.com/biography/Leo-Tolstoy

Nader, R., 1968, 'The great American gyp', The New York Review of Books, XI, 27-34.

Ndukwe, O., 2013, 'Consumerism: The backbone of ideological poverty in Africa (a Nigerian engagement)', Science Journal of Economics 2013, 6 pages, Article ID sje-164, viewed on 03 March 2016, from http://www.sjpub.org/sje/sje164.pdf

Njue, E. \& Muthaa, G., 2015, 'Influence of availability of sanitary facilities on the participation of the girl-child in public primary schools in Garissa County, Kenya' Open Journal of Social Sciences 3(8), 162-169. http://dx.doi.org/10.4236/ jss.2015.38018

Nugent, J.H. \& Werema, G., 2015, 'Does profit maximization impact sustainability? An examination', viewed 01 March 2016, from http://dx.doi.org/10.2139/ ssrn. 2637407

Odongo, W. \& Ng'ethe, V., 2015, 'Robberies, sex crimes and murders on the rise', Daily Nation, 07 July, viewed 11 March 2016, from http://www.nation.co.ke/news/ Crime-Statistics-Kenya-Nation-Newsplex/-/1056/2778984/-/q0m3ud/-/index. html

Ongiri, I., 2015, 'Kenya lands on US human trafficking list', Daily Nation, 28 September, viewed 11 March 2016, from http://www.nation.co.ke/news/ Kenya-lands-on-US-human-trafficking-list/-/1056/2888148/-/wvdqmy/-/index. html

Popova, M., 2014, 'Leo Tolstoy on finding meaning in a meaningless world', viewed 3 March 2016, from https://www.brainpickings.org/2014/06/03/tolstoy confession/

Purewal, S.J., 2015, '12 reasons you really don't need that new phone', viewed 26 February 2016, from http://www.greenbot.com/article/2985689/smartphones/ 12-reasons-you-really-don-t-need-that-new-phone.htm

Rubadiri, V., 2012, 'Kenyan youth spend Sh64b on clothes a year', viewed 29 February 2016, from http://www.capitalfm.co.ke/business/2012/06/kenyan-youth-spendsh64b-on-clothes-a-year/

Rural Poverty Portal, 2014, 'Rural Poverty in Kenya', viewed 03 March 2016, from http://www.ruralpovertyportal.org/country/home/tags/kenya

Sen, A., 1999, Development as Freedom, 1st edn., Oxford University Press, New York.

Shanin, T., 1972, The Awkward Class; Political Sociology of Peasantry in a Developing Society: Russia 1910-1925, Clarendon Press, New York.

Shi, D., 2001, Simple life: Plain living and high thinking in American culture, University of Georgia Press, London.
Shikwati, J., 2013, 'Consumerism: Why Kenya must rethink it', The African Executive, viewed on 29 February 2016, from http://www.africanexecutive.com/modules/ magazine/articles. php?article $=7019$

Soll, J.B., Keeney, R.L. \& Larrick, R.P., 2013, 'Consumer misunderstanding of credit card use, payments, and debt: Causes and solutions', Journal of Public Policy \& Marketing 32(1), 66-81. http://dx.doi.org/10.1509/jppm.11.061

Soriano, C.R.R., Lim, S.S. \& Rivera-Sanchez, M., 2015, 'The virgin Mary with a mobile phone: Ideologies of mothering and technology consumption in Philippine television advertisements', Communication, Culture \& Critique 8(1), 1-19. http://dx.doi.org/10.1111/cccr.12070

Swagler, R., 1979, Consumers and the market: An introductory analysis, 2nd edn., D.C. Heath, Lexington, KY.

Swagler, R., 1994, 'Evolution and applications of the term consumerism: Theme and variations', Journal of Consumer Affairs, 28(2), 347-360. http://dx.doi.org/ 10.1111/j.1745-6606.1994.tb00856.x

The Telegraph, 2010, 'Ten-year-olds have $f 7,000$ worth of toys but play with just f330', viewed on 26 February 2016, from http://www.telegraph.co.uk/finance/ newsbysector/retailandconsumer/8074156/Ten-year-olds-have-7000-worth-oftoys-but-play-with-just-330.htm

Townsend, J.A., 1998, 'The theology of Leo Tolstoy', Journal of the Grace Evangelical Society $11(20), 59-82$.

Townsend, P., 2013, International analysis of poverty, Routledge, London.

Van der Ploeg, J.D., 2008, The new peasantries: Struggles for autonomy and sustainability in an era of empire and globalisation, Earthscan, London.

Wallace, D. \& Wallace, S., 2001, Business studies, Heinemann Educational Publishers, Oxford.

Walloga, L., 2014, 'Sh1.3bn drugs ship blown up at sea', Daily Nation, 29 August, viewed 11 March 2016, from http://www.nation.co.ke/news/Drugs-Ship-Al-NoorMombasa/-/1056/2434958/-/bsrlfa/-/index.htm

Weis, T., 2007, The global food economy: The battles for the future of farming, Zed Books, London.

Whittington, R., 2013, Corporate strategies in recession and recovery: Social structure and strategic choice, Routledge, London.

Wilkens, S. \& Sanford, M.L., 2009, Hidden worldviews: Eight cultural stories that shape our lives, InterVersity Press, Downers Groove, IL.

World Bank Group, 2015, 'Overview', viewed 02 March 2016, from http://www. worldbank.org/en/country/kenya/overview

World Bank Group, 2016, Global monitoring report 2015/2016: Development goals in an era of demographic change, World Bank, Washington, DC. http://dx.doi. org/10.1596/978-1-4648-0669-8, viewed 2 March 2016, from http://pubdocs. worldbank.org/pubdocs/publicdoc/2015/10/503001444058224597/GlobalMonitoring-Report-2015.pdf

WorldWatch Institute, 2013, 'The state of consumption today', viewed 26 February 2016, from http://www.worldwatch.org/node/810 